\title{
区画内火災性状の簡易予測法 \\ A SIMPLE PREDICTIVE METHOD FOR ROOM FIRE BEHAVIOR
}

\author{
松山＼cjkstart賢*，藤田隆史*，金子英樹**，大宮喜文*** \\ 田中哮義****, 若松孝旺***

\section{Ken MATSUYAMA, Takashi FUJITA, Hideki KANEKO, Yoshihumi OHMIYA Takeyoshi TANAKA and Takao WAKAMATSU}

\begin{abstract}
Simple predictive equations for the room fire behavior were proposed. These were obtained by applying simple predictive method for pre-flashover compartment fire temperature proposed by Quintiere et al. to ventilation controlled fire. These equations can easily predict the temperature inside the compartment, the rate of heat loss due to ventilation and the rate of heat loss to compartment boundary. These can be used when the room fire is ventilation controlled regime. The results of the prediction using the simple equations were compared with the results of a more detailed computer model. Through this comparison, it was confirmed that these simple predictive equations are practical useful to estimate ventilation controlled compartment fire behavior, even though there is a little error caused by neglecting heat loss by radiation through the openings.
\end{abstract}

Keywords : room fire behaivior, simple predictive equation, ventilation controlled fire, radiation

区画内火災性状，簡易予測計算式，換気支配型火災，輻射

1.はじめに

耐火設計等において、区画内火炎性状は通常換気支配 の火災を仮定し、コンピューターモデルを用いて子予測され ている。そのため、時間の浪費を余儀なくされる場合が多 い。しかし、精度は幾分粗くてもコンピューターモデルに 代わる簡易な予測計算式があれば、実務的には非常に便利 であると考えられる。区画内火災性状を代表するものは、 先ず第一に区画内温度であるが、周壁への伝熱量は区画の 耐火性や延焼の問題に関係し、開口部からの流出熱量は避 難など区画外への様々な火災危険に影響する。そこで本研 究は、換気支配型燃焼を仮定した区画内火災性状（火災室 温度・開口部からの流出熱量・区画内周壁への失熱）の簡 易予測式を提案し、この簡易予測式をコンピューターモデ ルと比較し、実用性を検証することを目的として行った。

2. コンピューターモデルによる区画内火炎性状予測 ここでは、後に提案する簡易予測計算式と比較するた
めのコンピューターモデルについて、概要の説明とその 計算結果について述べる。

\section{1 予測モデルの概念}

本予測モデルは、盛期火災を対象として考えており、 区画内の温度をはじめ、全ての物理量が一様になってい ると仮定している。一般に室火災は多くの過程が有機的 に複合した現象である。そこで本モデルでは、火災室内 の現象を次のような過程に分けた熱的モデルに沿って火 災現象を考えている。

\section{（1）質量保存式}

盛期火災の区画内では、質量保存を考えた場合、次の ような式が成り立っている。

$$
\frac{d}{d t}\left(\rho_{F} V\right)=M+m_{a}-m_{g}
$$

\section{（2）エネルギー保存式}

火災室内におけるエネルギー保存式は、次式にて与え られる。
* 東京理科大学大学院理工学研究科

** 侏 NTTファシリティーズ・工修

****東京理科大学大学院理工学研究科 $\cdot$ 工修

****建設省建築研究所防煙研究室 室長 ·工博

******東京理科大学理工学部建築学科 教授工博
Graduate Student, Dept. of Architecture, Faculty of Sci. and Eng., Science Univ. of Tokyo

NTT Power and Building Facilities Inc., M. Eng.

Graduate Student, Dept. of Architecture, Faculty of Sci. and Eng, Science Univ. of Tokyo, M. Eng.

Head, Smoke Control Div., Building Research Institute, Ministry of Construction, Dr. Eng.

Prof. Dept. of Architecture, Faculty of Sci. and Eng., Science Univ. of Tokyo, Dr. Eng. 


$$
\begin{aligned}
\frac{d}{d t}\left\{c_{P} \rho_{F}\left(T_{F}-T_{\infty}\right) V\right\} & =Q_{C}-Q_{W}-Q_{R}-Q_{V} \\
& =Q_{C}-Q_{W}-Q_{R}-c_{P} m_{g}\left(T_{F}-T_{\infty}\right)
\end{aligned}
$$

\section{（3）状態式}

火災により誘起される微小な内外圧力差による空気密 度に対する影響及び、燃焼によるガス成分組成の変化は無 視し、本モデルでは、次のような状態方程式を用いる。

$$
\rho_{F} T_{F}=\rho_{\infty} T_{\infty}
$$

\section{（4）撚焼速度}

川越・関根は、実験的結果から燃焼速度 $M(\mathrm{~kg} / \mathrm{s})$ につい て次式のような半経験的な関係を示している11。

$$
M \approx 0.1 A \sqrt{H}
$$

この燃焼速度は、換気支配の火災性状をもたらし、幾 分の未然ガスが生ずる。但し、本モデルでは数值計算の安 定性を考虑して5分後に0.1A $\sqrt{H}(\mathrm{~kg} / \mathrm{s})$ となるように設定 している。

\section{（5）発熱量}

本モデルにおける可燃物の燃焼によって発生する熱量 $\mathbf{Q}_{\mathrm{C}}$ は、燃料支配時・換気支配時の $2 つ に$ 分けて考えてい る。以下にその関係式を示す。

- 燃料支配時 $\left(\mathbf{Q}_{\mathrm{C}}=\mathbf{Q}_{\mathrm{C} 1}\right)$

単位重量あたりに燃焼する木材の発熱量を $16,000(\mathrm{~kJ} / \mathrm{kg})$ として、次式のように考えられる。

$$
Q_{C 1}=16,000 M
$$

\section{·換気支配時 $\left(Q_{c}=Q_{c}\right)$}

単位空気消費あたりの発熱量は、燃料の種類に殆どよ

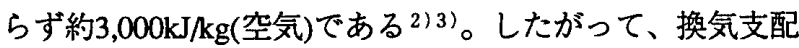
条件下では、流入空気が全て燃焼に使われると仮定すれ ば、

$$
\mathbf{Q}_{C 2}=3,000 m_{a}
$$

と考えることができる。これが火災室内で発生し得る最大 発熱速度である。

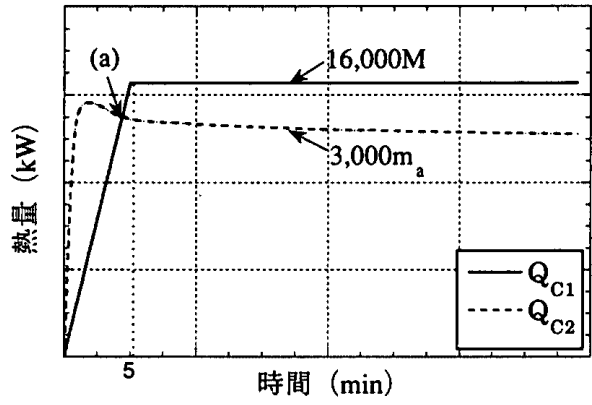

图1発熱速度の移り变わり

図にに、本モデルにおける発熱速度の移り変わりを示し ているが、 $Q_{\mathrm{C} 1}$ と $Q_{\mathrm{C}}$ が交わる点以前、すなわち、(a)点以 前は、燃料支配となり発熱速度は $Q_{\mathrm{c} 1}$ となる。(a)点以降 は、換気支配の火災性状もたらし発熱速度は $Q_{\mathrm{C} 2}$ となる。
また、このとき幾分の未燃ガスが生じる。本モデルで は、換気支配型燃焼を仮定しているので、(a)点以降を関 心の対象としている。

(6) 火出室温度

火炎室温度は式 $(2.1) \sim(2.3)$ の式より $\mathrm{T}_{\mathrm{F}}$ を陽に計算し た下式(2.7)を逐次計算して求めることができる。

$$
\begin{aligned}
\frac{d T_{F}}{d t}=\frac{T_{F}}{c_{P} \rho_{\infty} T_{\infty} V}\left(\mathrm{Q}_{C}-\mathrm{Q}_{W}-\mathrm{Q}_{R}\right) & \\
& -\frac{T_{F}}{\rho_{\infty} T_{\infty} V}\left(m_{a}+M\right)\left(T_{F}-T_{\infty}\right)
\end{aligned}
$$

\section{（7）周壁への失熱量}

内周壁等の境界構造面の温度は一様であるとするなら ば、熱量 $\mathrm{Q}_{\mathrm{w}}$ はそれらへの失輻射による熱伝達量と対流に よる熱伝達量の和である。すなわち、

$$
\mathrm{Q}_{W}=\varepsilon_{W} \sigma\left(T_{F}^{4}-T_{W}^{4}\right) A_{W}+\alpha_{W}\left(T_{F}-T_{W}\right) A_{W}
$$

なお $\mathrm{Q}_{\mathrm{w}}$ は、上式(2.8)に示すように境界構造表面温度 $\mathrm{T}_{\mathrm{w}}$ の関数となる。このため、火災の進行とともに变化す る $T_{\mathrm{w}}$ を別の求める必要がある。本モデルでは、下記の(1), (2)に示す 1 次元熱伝導方程式を差分法を使って数值的に求 めている。

(1)基準方程式

$$
\begin{aligned}
& -\left.k\left(\frac{d T}{d X}\right)\right|_{x=0}=q_{\text {in }}^{\prime \prime}(t) \\
& -\left.k\left(\frac{d T}{d X}\right)\right|_{x=1}=q_{\text {out }}^{\prime \prime}(t)
\end{aligned}
$$$$
\text { (2)境界条件 }
$$$$
\frac{d T}{d t}=\frac{k}{c \rho}\left(\frac{d^{2} T}{d X^{2}}\right)
$$

また、対流熱伝達率 $\alpha_{\mathrm{w}}$ を求めるため、

$$
T_{\alpha}=\left(T_{F}-T_{W}\right) / 2
$$

で定義される $\mathrm{T}_{\alpha}$ を用いて次式で定める4。

$$
\alpha_{W}= \begin{cases}5 \times 10^{-3} & \left(\mathrm{~T}_{\alpha} \leqq 300 \mathrm{~K}\right) \\ \left(0.02 T_{\alpha}-1\right) \times 10^{-3} & \left(300 \mathrm{~K}<\mathrm{T}_{\alpha}<800 \mathrm{~K}\right) \\ 15 \times 10^{-3} & \left(800 \mathrm{~K} \leqq \mathrm{~T}_{\alpha}\right)\end{cases}
$$

\section{（8）開口からの輻射失熱量}

火災及び空外部の物体の輻射率を1.0とすると開口から の輻射による失熱量 $Q_{R}$ は次式のように表せる。

$$
\mathrm{Q}_{R}=\sigma\left(T_{F}^{4}-T_{\infty}^{4}\right) A
$$

\section{(9) 換気量}

本モデルにおいては、一般的な火災の事例にならい、 中性帯の位置が開口上端と下端の間にできるという仮定 の下に、中性帯の高さ及び換気量を算出する。

$$
\begin{aligned}
& m_{a}=\frac{2}{3} \alpha B_{W}\left(2 g \rho_{F}|\Delta \rho|\right)^{1 / 2}\left(H_{h}-X_{n}\right)^{3 / 2} \\
& m_{g}=\frac{2}{3} \alpha B_{W}\left(2 g \rho_{\infty}|\Delta \rho|\right)^{1 / 2}\left(X_{n}-H_{l}\right)^{3 / 2}
\end{aligned}
$$


前述の理論に基づいて作成したコンピューターモデル の全体構成については、図2 に示す通りである。

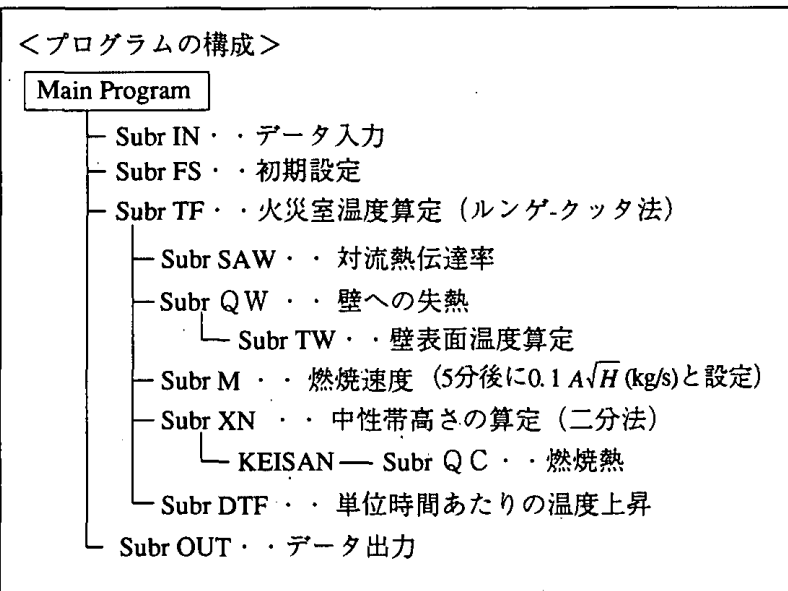

図2 計算プログラムの全体構成

\section{2 計算条件}

本予測モデルで区画内火災性状を把握するための計算 条件を以下に示す。

\section{(1) 区画条件}

事務所ビルの基準階面積別棟数・基準階平均面積等を 総合的に考えた結果、(1) $18^{\mathrm{w}}(\mathrm{m})-12^{\mathrm{D}}(\mathrm{m})-2.6^{\mathrm{H}}(\mathrm{m}) 、(2)$ $21^{\mathrm{w}}(\mathrm{m})-15^{\mathrm{D}}(\mathrm{m})-2.6^{\mathrm{H}}(\mathrm{m}) 、(3) 42^{\mathrm{w}}(\mathrm{m})-21^{\mathrm{D}}(\mathrm{m})-2.6^{\mathrm{H}}(\mathrm{m})$ の 3 条件 について計算を行う。

\section{（2）壁の材質}

壁の材質は、普通コンクリート・軽量コンクリート・ ALC板の3種類について計算を行う。但し、本モデルで使 用した壁材の熱伝導率 $\mathrm{k}(\mathrm{kW} / \mathrm{m} / \mathrm{K})$ 、比熱 $\mathrm{c}(\mathrm{kJ} / \mathrm{kg} / \mathrm{K})$ 、密度 $\rho\left(\mathrm{kg} / \mathrm{m}^{3}\right)$ の值については、表1に示す通りである。

\section{表1 壁材の熱特性}

\begin{tabular}{|c||c|c|c|}
\hline & $\begin{array}{c}\text { 熱伝導率 } \mathrm{k} \\
(\mathrm{kWW} / \mathrm{m} / \mathrm{K})\end{array}$ & $\begin{array}{c}\text { 比熱 } \mathrm{c} \\
(\mathrm{kJ} / \mathrm{kg} / \mathrm{K})\end{array}$ & $\begin{array}{c}\text { 密度 } \rho \\
\left(\mathrm{kg} / \mathrm{m}^{3}\right)\end{array}$ \\
\hline \hline 普通コンクリート & 0.00163 & 0.895 & 2250 \\
\hline 軽量コンクリート & 0.000523 & 1.39 & 1350 \\
\hline ALC板 & 0.000151 & 1.09 & 600 \\
\hline
\end{tabular}

(3) 温度因子 $\left(F_{0}\right)$

温度因子 $\mathrm{F}_{\mathrm{o}}=A \sqrt{H} / A_{T}$ のAは開口面積、Hは開口高さ、 $\mathrm{A}_{\mathrm{T}}$ は室内全表面積(開口部分も含む)である。区画の開口 条件を考えたとき、F。上限は2つの側面が全て開口であ ると仮定したときで十分であると考えられる。このとき の値はおよそ0.15である。したがって、 $F_{0}=0 〜 0.15$ の間 $(0.01,0.025,0.05,0.075,0.15)$ で計算を行う。

（1）（３）の条件を組み合わせ表2に示すようななパ夕 ーンで計算を行った。さらに、それぞれのパターンにつ いての火災室温度変化、開口部からの流出熱量比、およ び区画内周壁への熱損失比を算出する。
表2 計算パターン一覧

\begin{tabular}{|c|c|c|c|}
\hline 設定条件 & 区画条件変化 & 壁の材質変化 & 温度因子変化 \\
\hline $\begin{array}{l}\text { 区画 }(m) \\
(\mathrm{W} \times \mathrm{D} \times \mathrm{H})\end{array}$ & $\begin{array}{c}18-12-2.6 \\
21-15-2.6 \\
-\underline{42-2}-21-2.6 \\
\end{array}$ & \multicolumn{2}{|c|}{$18-12-2.6$} \\
\hline 壁の材質 & 普通コンクリート & $\begin{array}{c}\text { 普通コンンクリート } \\
\text { 軽量コンクリート } \\
\text { ALC板 }\end{array}$ & 普通コン \\
\hline 温度因子 & & $-1-=-2$ & \\
\hline
\end{tabular}

但し、火災荷重については全て $30\left(\mathrm{~kg} / \mathrm{m}^{2}\right)$ で計算を行う。

\section{3 計算結果}

（1）区画条件を変化させた場合の比較

図3 (a)〜 (c)に区画条件を変化させた場合の比較、すな わち区画の寸法のみを変化させそれ以外の条件は同一(壁

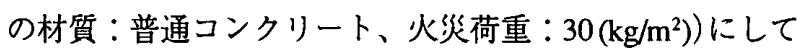
計算を行った結果の比較を示す。

火災継続時間に若干の違いはあるが、火災室温度変 化・開口部からの流出熱量比・周壁への失熱比は、全て の温度因子に対して合致している。このことから、換気 支配の火災性状は区画の規模によらず温度因子のみで決 まるということが分かる。

\section{（2）壁の材質を变化させた場合の比較}

図4 (a)〜 (c)に壁の材質のみを変化させ、それ以外の条 件は同一(区画寸法：18-12-2.6(m)、火災荷重：30(kg/m²)) にして計算を行った結果の比較を示す。

熱伝導率 $\mathrm{k}(\mathrm{kW} / \mathrm{m} / \mathrm{K})$ は、普通コンクリート $(0.00163)>$ 軽量コンクリート $(0.000523)>\mathrm{ALC}$ 板 $(0.000151)$ となって おり、 $\mathrm{k}$ が高い材質ほど熱を通しやすい性質であるので、 火災室温度変化・開口部からの流出熱量比については ALC板 > 軽量コンクリ゙ート>普通コンクリートとなり、 周壁への失熱比については、この逆になったと考えられ る。

なお、5種類の温度因子のついて、図3, 図4と同様の計 算を行なっているが、すべて同じ傾向を示すため、ここ では、 $\mathrm{F}_{\mathrm{o}}=0.01$ のみを示した。

\section{（3）温度因子を変化させた場合の比較}

図5 (a)〜 (c)に壁の材質のみを変化させ、それ以外の条 件は同一(区画寸法：18-12-2.6 (m)、壁の材質：普通コン クリート、火災荷重：30( $\left.\left.\mathrm{kg} / \mathrm{m}^{2}\right)\right)$ にして計算を行った結果 の比較を示す。

グラフを見ると、火災室温度変化および開口部からの 流出熱量比は、温度因子が大きいほど值が大きくなり、 周壁への失熱比は小さいほど大きくなっている。これ は、本モデルが換気支配然焼を仮定しているため、開口 が大きくなれば、区画内への流入空気量が多くなり、区 画内での発熱量も大きくなるためであると考えられる。 また、温度因子が大きいほど火災継続時間が短くなって いるが、これは、火災荷重と区画寸法を同一の条件で計 算を行っているため、開口が大きいほど然焼速度が大き くなり、可然物が早く燃え尽きてしまうからである。 


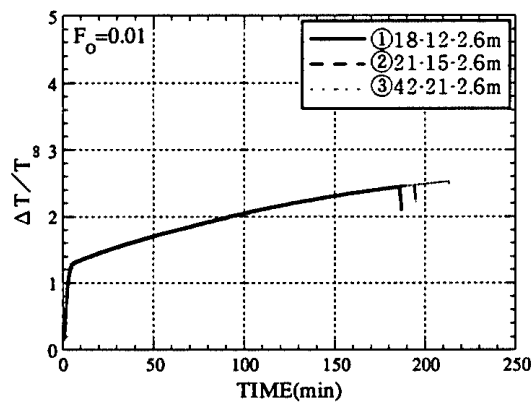

(a) 火炎室温度変化

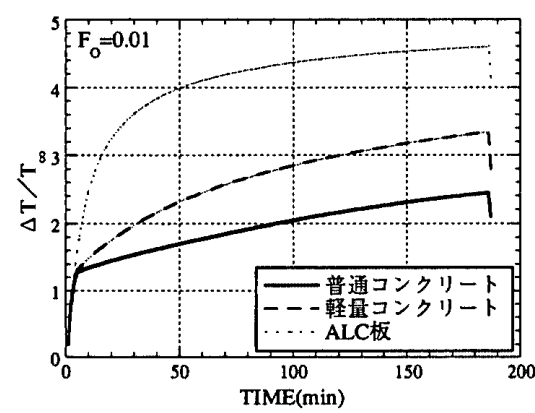

(a) 火炎室温度变化

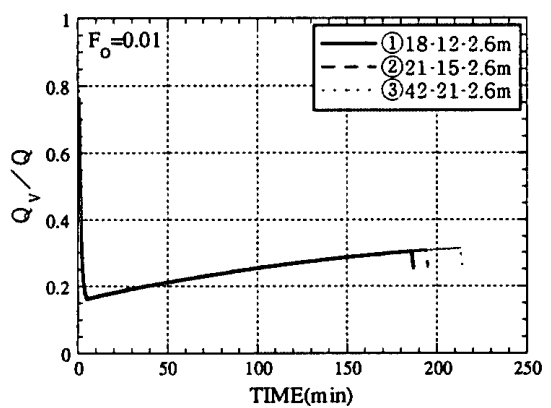

(b) 開口部からの流出熱量比

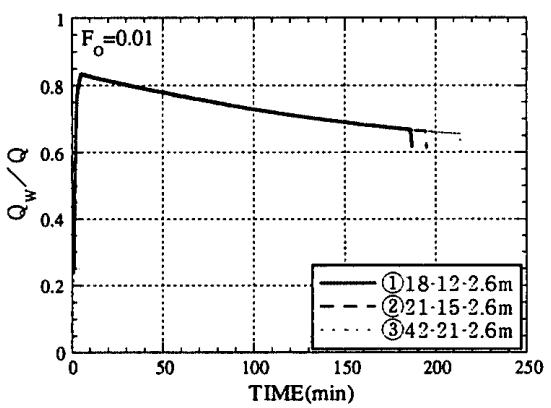

(c) 周壁への失熱比

図3 コンピューターモデルの計算結果 (区画条件変化)

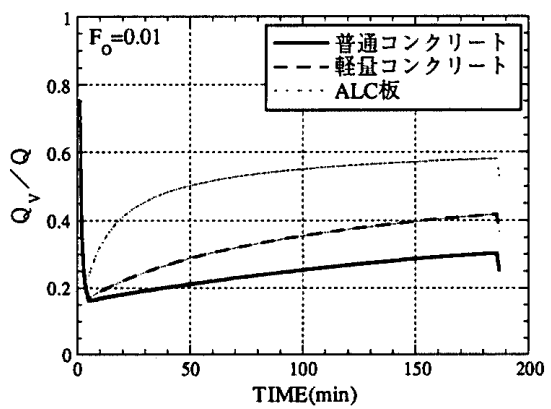

（b）開口部からの流出熱量比

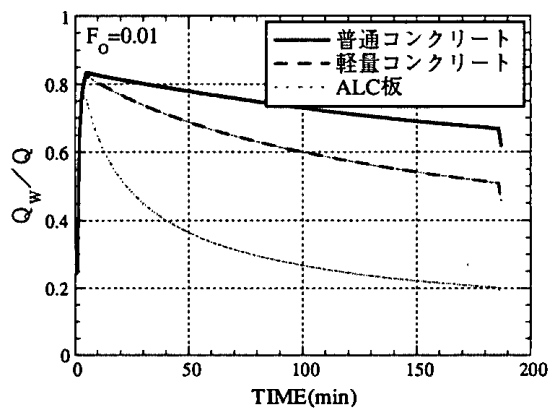

（c）周壁への失熱比

図4 コンピューターモデルの計算結果（壁の材質変化）

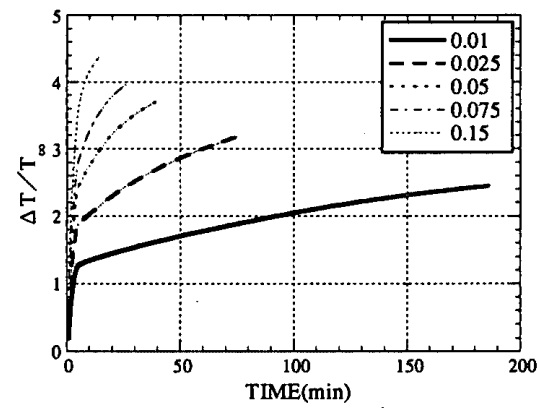

(a) 火炎室温度変化

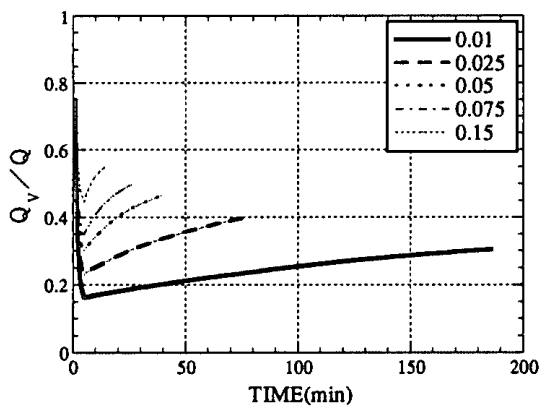

(b) 開口部からの流出熱量比

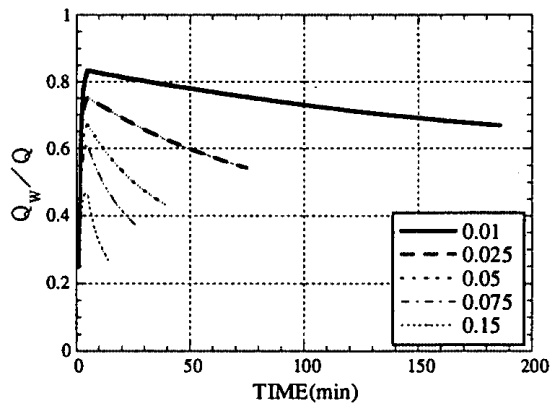

（c）周壁への失熱比

図5 コンピューターモデルの計算結果(温度因子变化)

\section{3. 区画内火災性状の簡易予測法}

\section{1 簡易予測計算式}

本研究では、Quintiereらにより提案された火災初期の 火災室温度についての簡易予測法を基に、換気支配時の 火災室内における温度変化、開口部からの流出熱量拉よ び区画内周壁への熱損失を簡易に予測するための計算式 を提案する。

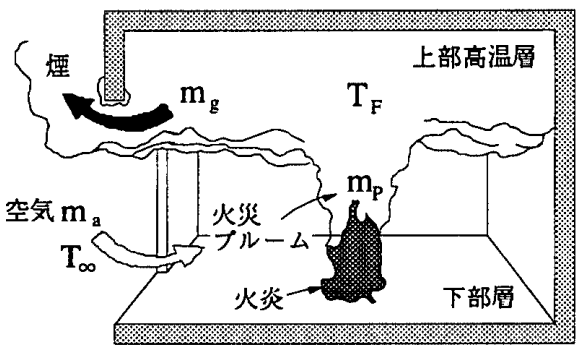

図6 初期火炎時の室内の様子
火災室温度はQuintiereらによれば煙層の質量バラン ス、 $\mathrm{m}_{\mathrm{g}}$ は開口因子 $A \sqrt{H}$ と温度の関数であることを考慮 し、多くの実験結果による回帰により、火災室内での発 熱速度がQの時、次式にて与えられている5)。

$\frac{\Delta T}{T_{\infty}}\left(=\frac{T_{F}-T_{\infty}}{T_{\infty}}\right)=1.6\left(\frac{\mathrm{Q}}{\sqrt{g} c_{p} \rho_{\infty} T_{\infty} A \sqrt{H}}\right)^{2 / 3}\left(\frac{h_{k} A_{T}}{\sqrt{g} c_{p} \rho_{\infty} A \sqrt{H}}\right)^{-1 / 3}$

但し、 $h_{k}=\left(\frac{k \rho c}{t}\right)^{1 / 2}$

（1）火炎室温度 $\Delta T / T_{\infty}$

換気支配時の火災において火災室内への流入空気量 $\mathrm{m}_{\mathrm{a}}$ は、概ね

$$
m_{a} \approx 0.5 A \sqrt{H}
$$

で与えられることが知られている2う。また、単位空気当た りの発熱量は燃料の種類によらず $3,000(\mathrm{~kW})$ で殆ど一定で あるから、火災室内での発熱速度Qは 


$$
\mathrm{Q} \approx 1,500 A \sqrt{H}
$$

となる。よって式(3.1)と式(3.4)から

$$
\begin{aligned}
\frac{\Delta T}{T_{\infty}} & \propto\left(\frac{1,500 A \sqrt{H}}{\sqrt{g} c_{P} \rho_{\infty} T_{\infty} A \sqrt{H}}\right)^{2 / 3}\left(\frac{h_{k} A_{T}}{\sqrt{g} c_{P} \rho_{\infty} A \sqrt{H}}\right)^{-1 / 3} \\
& \propto\left(\frac{A \sqrt{H}}{A_{T}}\right)^{1 / 3}\left(\frac{1}{h_{k}}\right)^{1 / 3}
\end{aligned}
$$

と表すことができる。これに、式(3.2)を代入すると次の ように与えられる。

$$
\frac{\Delta T}{T_{\infty}}=C_{1}\left(\frac{A \sqrt{H}}{A_{T}}\right)^{1 / 3}\left(\frac{t}{k \rho c}\right)^{1 / 6} \quad \text { (C } 1 \text { は定数) }
$$

\section{（2）開口部からの流出熱量比 $Q_{v} / Q$}

開口部からの流出熱量 $\mathrm{Q}_{\mathrm{v}}$ は次式で与えられる。

$$
\mathrm{Q}_{V}=c_{P} m_{g} \Delta T
$$

ここで $\mathrm{m}_{\mathrm{g}} \propto A \sqrt{H}$ 、また発熱速度 $\mathrm{Q}$ は式 (3.4)加分か

るようにQ $\propto A \sqrt{H}$ であるから、 $\mathbf{Q}_{v} / \mathbf{Q}$ は $\Delta \mathrm{T}$ 比例してい ることが分かるので、次のように与えられる。

$$
\frac{\mathrm{Q}_{V}}{\mathrm{Q}}=C_{2}\left(\frac{A \sqrt{H}}{A_{T}}\right)^{1 / 3}\left(\frac{t}{k \rho c}\right)^{1 / 6} \quad\left(\mathrm{C}_{2} \text { は定数 }\right)
$$

\section{（3）区画内周壁への熱損失比 $Q_{W} / Q$}

区画内周壁への熱損失 $\mathrm{Q}_{\mathrm{w}}$ は

$$
\mathrm{Q}_{W}=h_{k} \Delta T A_{T}
$$

と表現できるとすると、開口部からの流出熱量と同様 に、式(3.4)を考慮して $\mathrm{Q}_{\mathrm{W}} / \mathrm{Q}$ は次のように与えられること になる。

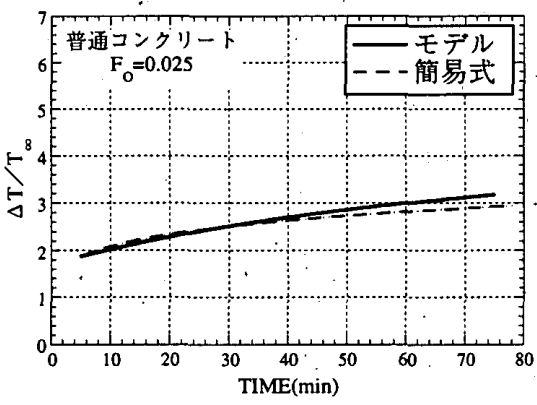

(a) 火炎室温度变化

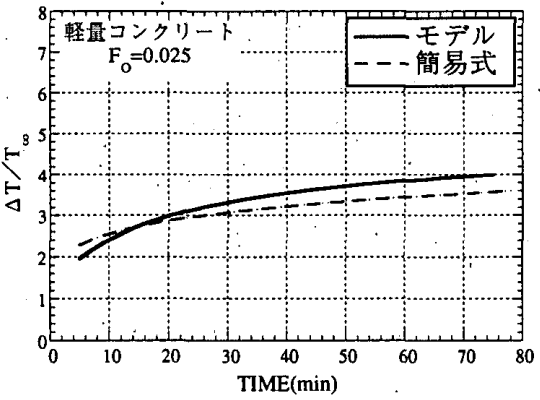

(a) 火災室温度变化

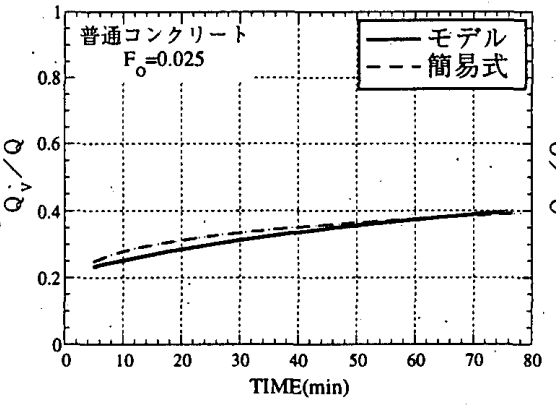

（b）開口部からの流出熱量比

$$
\frac{\mathrm{Q}_{W}}{\mathrm{Q}}=C_{3}\left(\frac{A \sqrt{H}}{A_{T}}\right)^{-2 / 3}\left(\frac{t}{k \rho c}\right)^{-1 / 3} \quad\left(\mathrm{C}_{3} \text { は定数 }\right)
$$

\section{2 簡易予測計算式の回帰結果}

コンピューターモデルの計算結果を簡易予測計算式に 回帰させて係数を求めた結果、次のようになった。

$$
\begin{aligned}
& \frac{\Delta T}{T_{\infty}}=3.0\left(\frac{A \sqrt{H}}{A_{T}}\right)^{1 / 3}\left(\frac{t}{k \rho c}\right)^{1 / 6} \\
& \frac{\mathrm{Q}_{V}}{\mathrm{Q}}=0.4\left(\frac{A \sqrt{H}}{A_{T}}\right)^{1 / 3}\left(\frac{t}{k \rho c}\right)^{1 / 6} \\
& \frac{\mathrm{Q}_{V 2}}{\mathrm{Q}}=0.45\left(\frac{A \sqrt{H}}{A_{T}}\right)^{1 / 3}\left(\frac{t}{k \rho c}\right)^{1 / 6} \\
& \frac{\mathrm{Q}_{W}}{\mathrm{Q}}=0.45\left(\frac{A \sqrt{H}}{A_{T}}\right)^{-2 / 3}\left(\frac{t}{k \rho c}\right)^{-1 / 3}
\end{aligned}
$$

但し、 $Q_{v} / Q ， Q_{v_{2}} / Q$ はそれぞれ、輻射による失熱を含ま ない開口部からの流出熱量比、輻射による失熱を含志開 口部からら流出熱量比である。また、周壁への失熱比 $\mathrm{Q}_{\mathrm{w}} /$ Qを考えた場合、時間圤初期の方で1を越えてしまうとい うことと、コンピューターモデルの計算值とあまり合致 しないないということから $\mathrm{Q}_{\mathrm{w}}+\mathrm{Q}_{\mathrm{V} 2}=\mathrm{Q}$ であることを利用し 次のような簡易式を提案する。

$$
\frac{\mathrm{Q}_{W}}{\mathrm{Q}}=1-0.45\left(\frac{A \sqrt{H}}{A_{T}}\right)^{1 / 3}\left(\frac{t}{k \rho c}\right)^{1 / 6}
$$

なお、式(3.11)の係数3.0は、式(3.5)の定数 $\mathrm{c}_{\mathrm{p}}, \mathrm{g}, \mathrm{T}_{\infty}, \rho_{\infty}$ に具体的な数值を代入しても得られる。

図7 モデル值と簡易式の比較(普通コンクリート)

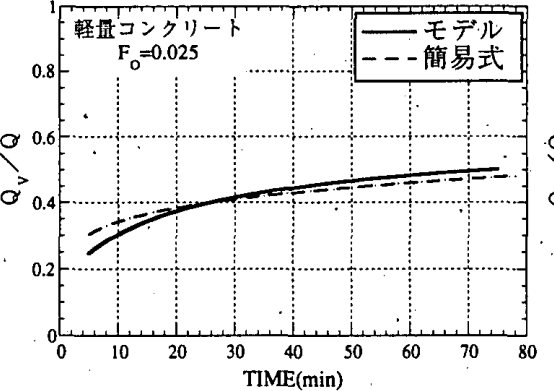

(b) 開口部からの流出熱量比

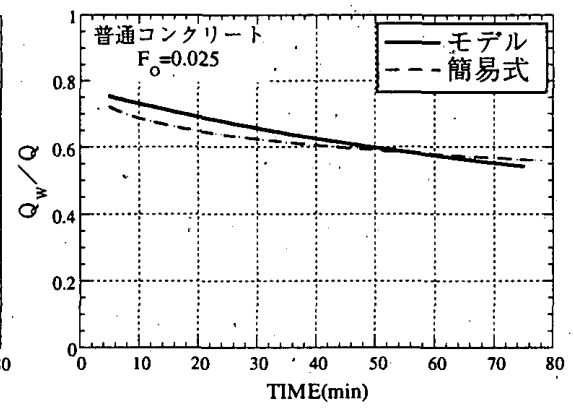

（c）周壁への失熱比

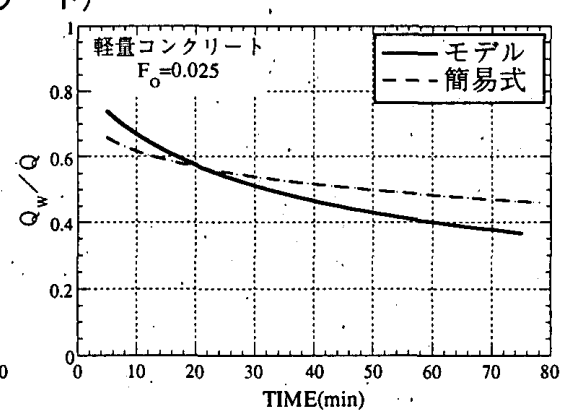

（c）周壁への失熱比

図8 モデル值と簡易式の比較(軽量コンクリート) 


\section{3 简易予測計算式とモデル值との比較・考察}

図7は普通コンクリート、図8は軽量コンクリートにつ いてのコンピューターモデルの計算值と簡易予測計算式 ((a)火災室温度は式(3.11)、(b)開口部からの流出熱量比は 式(3.12)、(c)周壁への失熱比は式(3.15))を比較したグラフ である。但し、ここで示したのは、温度因子 $\mathrm{F}_{\mathrm{o}}=0.025$ の場 合である。

普通コンクリート、軽量コンクリートとも火災室温度

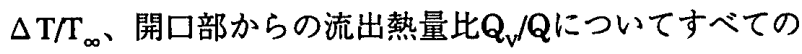
温度因子 $\mathrm{F}_{\mathrm{o}}=A \sqrt{H} / A_{T}$ に対してコンピューターモデルの 計算值と簡易予測計算式はほほ合致したといえる。しか し、軽量コンクリートの周壁への失熱比 $\mathrm{Q}_{\mathrm{w}} / \mathrm{Q}$ は温度因子 が大きくなるにつれて合わなくなってしまった。これは、 簡易予測計算式において開口部からの流出熱量 $Q_{V}$ を $Q_{v}=c_{p} m_{g} \Delta T$ としており、輻射による失熱を式自体に含ん でいないが、輻射による失熱を考慮したコンピュータモデ ルの計算値に簡易予測計算式を回帰させた $Q_{\mathrm{V} 2} / \mathrm{Q}$ 熱収支 式 $\mathrm{Q}_{\mathrm{w}}+\mathrm{Q}_{\mathrm{v} 2}=\mathrm{Q}$ から $\mathrm{Q}_{\mathrm{w}} / \mathrm{Q}$ (すなわち式(3.15))を求めているこ とに起因する。つまり、軽量コンクリートは熱伝導率の小 さい材質であること、また開口が大きくなることから、火 災室温度は高くなり、輻射による失熱は大きくなるはずで あるが、簡易予測計算式においてこれを小さく見積もって しまったために誤差が生じたと考えられる。

以上のようなことより、火災室温度変化と開口部から の流出熱量比については火災初期段階において安全側の予 測ができることが分かった。しかし、周壁への失熱比につ いては、輻射による失熱の見積もり方に課題を残すことに なった。また、区画内火災性状を簡易に予測する上で温度 因子と壁の材質が大きく影響することが明らかになった。

\section{4.まとめ}

コンピューターモデルでの火災性状予測の結論とし て、換気支配を仮定した火災の性状について、次のことが 言える。

・火災性状は、区画の規模によらず温度因子のみに

よって定まる。

・火災性状には、壁の材質が大きく影響する。

簡易予測計算式は、Quintiere等によるpre-flashover火災 に対する予測式を換気支配火災に拡大適用したものである が、輻射による失熱の見積もり方に問題は残るものの、温 度因子がある程度小さい場合、また、熱伝導率がある程度 大きい場合には、コンピューターモデルによる予測結果と ほぼ合致し、その実用性を確認することができたと言え る。さらに、実用的なものにするためには以下の問題点を 解決していく必要があると思われる。

・輻射による失熱を含んだ簡易予測計算式を導く。

・1室についての予測式でなく、2室・3室における

簡易予測計算式を導く。

\section{<記号説明>}

A : 区画開口の面積 $(\mathrm{m})$

$A_{\mathrm{T}}$ : 区画内の周壁面皘 $\left(\mathrm{m}^{2}\right)$

$\mathrm{A}_{\mathrm{w}}$ : 境界構造面の面積 $\left(\mathrm{m}^{2}\right)$

$\mathrm{B}_{\mathrm{w}}$ : 開口幅 $(\mathrm{m})$

c : 壁材の比熱 $(\mathrm{kJ} / \mathrm{kg} / \mathrm{K})$

$c_{\mathrm{p}}:$ 気体の定圧比熱 $(\mathrm{kJ} / \mathrm{kg} / \mathrm{K})$

$\mathrm{F}_{\mathrm{o}}$ : 温度因子 $\left(A \sqrt{H} / A_{T}\right)$

$\mathrm{g}:$ 重力加速度 $\left(\mathrm{m} / \mathrm{s}^{2}\right)$

$\mathrm{H}$ : 区画開口高さ $(\mathrm{m})$

$\mathrm{H}_{\mathrm{h}}$ : 開口上端までの高さ $(\mathrm{m})$

$\mathrm{H}_{1}$ : 開口下端までの高さ $(\mathrm{m})$

$\mathrm{h}_{\mathrm{k}}$ : 熱伝達率 $\left(\mathrm{kW} / \mathrm{m}^{2} / \mathrm{K}\right)$

$\mathrm{k}$ : 壁材の熱伝導率 $(\mathrm{kW} / \mathrm{m} / \mathrm{K})$

1 : 壁材の厚さ $(\mathrm{m})$

M : 燃焼速度 $(\mathrm{kg} / \mathrm{s})$

$\mathrm{m}_{\mathrm{a}}$ : 開口からの流入空気量 $(\mathrm{kg} / \mathrm{s})$

$\mathrm{m}_{\mathrm{g}}$ : 開口からの高温ガス流出量 $(\mathrm{kg} / \mathrm{s})$

$\mathrm{m}^{\mathrm{g}}$ : 火災プルームによる高温層への流入量 $(\mathrm{kg} / \mathrm{s})$

$\mathbf{Q}:$ 発熱速度 $(\mathrm{kJ} / \mathrm{s}=\mathrm{kW})$

$\mathrm{Q}_{\mathrm{C}}$ : 燃焼熱量 $(\mathrm{kW})$

$\mathbf{Q}_{\mathrm{R}}$ : 空からの輻射失熱量 $(\mathrm{kW})$

$\mathrm{Q}_{\mathrm{v}}$ : 噴出火炎の持ち去り熱量 $(\mathrm{kW})$ 開口部から流出する熱量 $(\mathrm{kW})$

$Q_{\mathrm{v} 2}$ ：輻射による失熱を含む開口部から流出する熱量 $(\mathrm{kW})$

$\mathrm{Q}_{\mathrm{w}}$ : 周壁への失熱量 $(\mathrm{kW})$

$\dot{q}_{i n}^{\prime \prime}$ : 壁材の加熱面功の入射熱流束 $\left(\mathrm{kW} / \mathrm{m}^{2}\right)$

$\dot{q}_{\text {oul }}^{\prime \prime}$ : 壁材の非加熱面からの失熱流束 $\left(\mathrm{kW} / \mathrm{m}^{2}\right)$

$\mathrm{T} \quad:$ 温度 $(\mathrm{K})$

$\mathrm{T}_{\mathrm{F}}$ : 火災室温度 $(\mathrm{K})$

$\mathrm{T}_{\mathrm{w}}$ : 境界構造表面温度 $(\mathrm{K})$

$\mathrm{T}_{\infty}$ : 雾囲気 (外気) 温度 $(\mathrm{K})$

$\Delta \mathrm{T}:$ 火災室内と外気の温度差 $\left(=\mathrm{T}_{\mathrm{F}}-\mathrm{T}_{\infty}\right)(\mathrm{K})$

$\mathrm{t}:$ 時間 (s)

$\mathrm{V}:$ 容積 $\left(\mathrm{m}^{3}\right)$

$\mathrm{X}$ : 壁体の奥行方向距離 $(\mathrm{m})$

$\mathrm{X}_{\mathrm{n}} \quad$ : 中性帯の高さ $(\mathrm{m})$

$\alpha \quad$ : 流量係数

$\alpha_{\mathrm{w}}:$ 对流熱伝達率 $\left(\mathrm{kW} / \mathrm{m}^{2} / \mathrm{K}\right)$

$\varepsilon_{\mathrm{w}}$ : 境界構造面の輻射率

$\rho:$ 壁材の密度 $\left(\mathrm{kg} / \mathrm{m}^{3}\right)$

$\rho_{\mathrm{F}}$ : 火災室の空気密度 $\left(\mathrm{kg} / \mathrm{m}^{3}\right)$

$\rho_{\infty}$ : 需囲気(外気)の空気密度 $\left(\mathrm{kg} / \mathrm{m}^{3}\right.$ )

$\Delta \rho:$ 火災室内と外気の空気密度差 $\left(=\rho_{\infty}-\rho_{\mathrm{F}}\right)\left(\mathrm{kg} / \mathrm{m}^{3}\right)$

$\sigma \quad:$ ステファン・ボルツマン定数 $5.67051 \times 10^{-8}\left(\mathrm{~W} / \mathrm{m}^{2} / \mathrm{K}^{4}\right)$

\section{【参考文塥】}

1）川越邦雄，関根孝：壁体の熱伝導率の違いによるコンクリート造 建物内の火災温度曲線の推定, 日本火炎学会論文集, Vol. 13, No. 1 (1963)

2) 田中哮转：建築火災安全工学入門, 日本建築センター（1993）

3 ) Huggett, C. : Estimation of Rate of Heart Release by Means of Oxygen Consumption Method, Fire and Materials, Vol. 4, No. 2 (1980)

4）田中哮義, 中村和人：<二層ゾーンの概念に基づく〉建物内煙流 動予測計算モデル，建築研究報告No.123，建設省建築研究所（1989）

5) McCaffery, B. J. Quintiere, J. G. and Harkleroad, M. F. : Estimating Room Temperatures and the Likelihood offrashover Using Fire Test Data Correlations, Fire Technology, Vol. 17, No. 2, 98-119 (1981)

6) 国土開発技術センター編：建築物の総合防火設計法（第 4 巻 耐火 設計法），日本建築センター（1989）

7) Dougal Dryadale : An Introduction To Fire Dynamics (1985)

8）大宮喜文：噴出火炎による上階延焼予湘に関する研究，建築学会 大会学術講演梗概集, 日本建等学会 (1993)

（1994年10月 7 日原稿受理，1994年12月22日採用決定） 